Reprod. Nutr. Dévelop., 1981, 21 (5A), 715-726.

\title{
In vitro effect of a fish gonadotropin on aromatase and $17 \beta$-hydroxysteroid dehydrogenase activities in the ovary of the rainbow trout (Salmo gairdneri Rich.)
}

par O. SIRE, J. DÉPÊCHE

Université Pierre-et-Marie-Curie

Laboratoire de Physiologie de la Reproduction des Vertébrés

4, place Jussieu, 75230 Paris Cedex 05, France.

Summary. Aromatase activity has been studied in the rainbow trout ovary in a perifusion system. During early vitellogenesis, as in other stages of the annual cycle, the ovaries were capable of aromatizing androstenedione and testosterone. Aromatase activity increased from the postovulatory stages to exogenous vitellogenesis.

When highly purified salmon glycoprotein maturational gonadotropin was added to the medium $(50 \mathrm{ng} / \mathrm{ml})$, the androstenedione/testosterone ratio was reduced by half. This indicates a stimulation of $17 \beta$-hydroxysteroid dehydrogenase activity favourizing the formation of testosterone. At a concentration of 50,150 or $300 \mathrm{ng} / \mathrm{ml}$, the gonadotropin inhibited between 13 and 38 p. 100 of the aromatase enzymatic activity.

\section{Introduction.}

In most temperate zone fish, seasonal sexual activity corresponds to adaptation to the changing environment. The endocrine system is the link between the various environmental regulators (e.g. photoperiod, temperature) and the gametogenetic processes. In the female, annual variation of estrogen secretion is the major, best-known cyclic phenomenon affecting ovarian activity (Billard ef al., 1978). An increase in the plasma levels of immunoreactive estradiol $-17 \beta$ during ovarian recrudescence has been shown in various teleosts as the rainbow trout (Lambert ef al., 1978), the brown trout (Crim and Idler, 1978), the plaice (Wingfield and Grimm, 1977) and Tilapia (Yaron et al., 1977).

During the period of gonadal recrudescence in the female trout, there is a parallel increase in plasma gonadotropin and estradiol-17 $\beta$ levels (Breton et al., 1975 ; Fostier et al., 1978). But such a correlation does not exist at the end of the reproductive cycle : the estradiol-17 $\beta$ level drops before oocyte maturation, whereas the gonadotropin (GTH) level remains high for more than two weeks after ovulation (Breton et al., 1975 ; Fostier ef al., 1978).

In order to understand these changes in the gonadotropin-estradiol relation, we studied aromatase activity in the rainbow trout (Salmo gairdneri Rich.) at different stages of the annual ovarian cycle, observing the effect of a fish gonadotropin on the biosynthesis of estrogens. 


\section{Materials and methods.}

Collection and treatment of the fish. - Three-year old female rainbow trout were obtained from the Experimental troutculture station of « Gaz de France » at Gournay. The individual fish parameters are shown in table 1. The fish, in their second reproduc-

TABLE 1

Parameters of the individual fishes

\begin{tabular}{|c|c|c|c|c|c|c|c|c|}
\hline Animal & $\begin{array}{l}\text { Date of } \\
\text { experiment }\end{array}$ & $\begin{array}{r}\text { Post-o } \\
d\end{array}$ & $\begin{array}{l}\text { vulatory } \\
\text { delay }\end{array}$ & $\begin{array}{l}\text { Standard } \\
\text { length }(\mathrm{cm})\end{array}$ & $\begin{array}{l}\text { Body } \\
\text { weight } \\
\text { (g) }\end{array}$ & $\begin{array}{l}\text { Ovary } \\
\text { weight } \\
\text { (g) }\end{array}$ & GSI * & $\begin{array}{c}\text { Mean diameter of } \\
\text { largest oocytes } \\
(\mu \mathrm{m})\end{array}$ \\
\hline 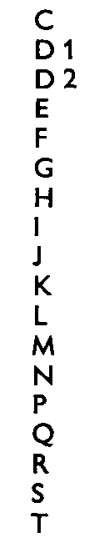 & $\begin{array}{l}23 / 11 / 78 \\
30 / 11 / 78 \\
30 / 11 / 78 \\
12 / 12 / 78 \\
20 / 12 / 78 \\
21 / 02 / 79 \\
27 / 02 / 79 \\
01 / 03 / 79 \\
21 / 03 / 79 \\
22 / 03 / 79 \\
28 / 03 / 79 \\
06 / 04 / 79 \\
23 / 04 / 79 \\
12 / 06 / 79 \\
14 / 06 / 79 \\
29 / 06 / 79 \\
09 / 07 / 79 \\
10 / 07 / 79\end{array}$ & $\begin{array}{c}10 \\
0 \\
4 \\
15 \\
25 \\
1 \\
1 \\
2 \\
2 \\
2-3 \\
2-3 \\
2-3 \\
3 \\
5 \\
6 \\
6 \\
6 \\
6\end{array}$ & $\begin{array}{l}\text { days } \\
\text { days } \\
\text { days } \\
\text { days } \\
\text { days } \\
\text { month } \\
= \\
= \\
= \\
= \\
= \\
= \\
= \\
= \\
=\end{array}$ & $\begin{array}{l}37.0 \\
33.0 \\
35.5 \\
36.0 \\
37.0 \\
35.0 \\
35.5 \\
38.0 \\
35.0 \\
33.5 \\
40.5 \\
31.0 \\
38.0 \\
43.0 \\
48.5 \\
45.0 \\
40.0 \\
48.0\end{array}$ & 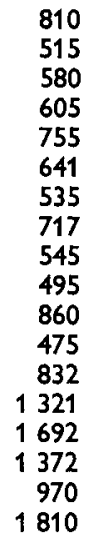 & $\begin{array}{c}5.42 \\
Z^{* *} \\
7.69 \\
17.76 \\
4.91 \\
2.82 \\
6.02 \\
2.87 \\
2.57 \\
5.02 \\
3.12 \\
4.19 \\
7.94 \\
3.48 \\
9.69 \\
8.79 \\
28.18\end{array}$ & $\begin{array}{l}0.67 \\
\overline{-} \\
1.27 \\
2.30 \\
0.76 \\
0.52 \\
0.84 \\
0.53 \\
0.52 \\
0.58 \\
0.66 \\
0.50 \\
0.60 \\
0.20 \\
0.70 \\
0.91 \\
1.55\end{array}$ & $\begin{array}{r}460 \\
440 \\
440 \\
450 \\
450 \\
724 \\
766 \\
510 \\
599 \\
630 \\
670 \\
679 \\
546 \\
970 \\
970 \\
800 \\
1180 \\
1150 \\
1200\end{array}$ \\
\hline
\end{tabular}

* The GSI is the ratio of gonadal fresh weight/intact body fresh weight $\times 100$.

** Not measured.

tive cycle, were kept in aquaria for several days before experimentation. They were anesthetized by immersion in a phenoxy-2-ethanol solution ( 0.03 p. 100) for 5 min. under strong bubbling air. All handling was carried out in a sterile atmosphere at $14{ }^{\circ} \mathrm{C}$. The ovaries were removed, weighed and washed in gas-equilibrated Eagle's medium (Eagle, 1959) for 5 to $10 \mathrm{~min}$. Some fragments were weighed and others were fixed for microscopic examination.

Radioactive steroids $\left({ }^{1}\right) .-\left[7(\mathrm{n}){ }^{3} \mathrm{H}\right]-$ Androstenedione (specific activity : $15 \mathrm{Ci} /$

(1) Trivial and systemic names of the steroids and other hormones quoted in the text:

Pregnenolone : 3 $\beta$-hydroxy-5-pregnen-20-one.

Progesterone : 4-pregnene-3,20-dione.

$17 \alpha$ hydroxy-20 $\beta$ dihydroprogesterone : $17 \alpha, 20 \beta$-dihydroxy-4-pregnen-3-one.

Androstenedione : 4-androstene-3,17-dione.

Androstanedione : $5 \alpha / \beta$-androstane-3,17-dione. 
mmol), $\left[7(\mathrm{n}){ }^{3} \mathrm{H}\right]$ testosterone $(8.9 \mathrm{Ci} / \mathrm{mmol}),\left[4-{ }^{14} \mathrm{C}\right]$-estrone $(52 \mathrm{Ci} / \mathrm{mol})$ and $\left[4-{ }^{14} \mathrm{C}\right]$ -estradiol-17 $\beta$ (52 Ci/mol) were obtained from the Radiochemical Centre (Amersham). They were determined as chromatographically pure before use : thin-layer chromatography in a chloroform : ethyl acetate system $(5: 1)$. All non-radioactive steroids were obtained from the Sigma Chemical Co.

Gonadotropic hormone. - Highly purified salmon (Oncorhynchus tshawytsha) gonadotropin was prepared according to Breton ef al. (1978). Its specific activity was assayed by the in vitro maturation of trout oocytes according to Jalabert ef al. (1974).

Experimental design. - We used a perifusion system identical to that which Ménézo (1976) described for the culture of mammalian follicles. Ovarian fragments of about $300 \mathrm{mg}(313.7 \pm 17.7 ; \mathrm{n}=38)$ were incubated in the Ménézo B2 medium (Ménézo, 1976), equilibrated with a gas mixture : $\mathrm{N}_{2} 50$ p. $100, \mathrm{O}_{2} 49$ p. 100, $\mathrm{CO}_{2}$ 1 p. 100. A low concentration of carbon dioxide was used because of its solubility at $14^{\circ} \mathrm{C}$. In these conditions, the $\mathrm{pH}$ was 7.9, a value similar to that measured in the coelomic fluid (Jalabert, personal communication). The values of osmotic pressure and ionic strength were close to those of trout plasma values (Jalabert, personal communication). The perifused volume was $13 \mathrm{ml}$; its mean flow through the culture chamber was $200 \mathrm{ml} / \mathrm{hr}$. Incubation was always started at 11.00 and stopped at $17.00 \mathrm{hrs}$, except in the case of kinetic studies which continued for 2, 6 and 24 hrs.

Steroid precursor concentration was adjusted by the addition of unlabeled purified steroids to obtain a specific activity of $31.6 \times 10^{6}$ or $31.1 \times 10^{4} \mathrm{dpm} / \mathrm{nmol}$. The precursors were introduced into the medium as soon as incubation began. If GTH was then needed, it was added immediately at a concentration of 50,150 or $300 \mathrm{ng} / \mathrm{ml}$. As the steroids were adsorbed on the silastic tubes of the perifusion circuit, we limited the length of that tubing to the minimum needed for the functioning of the peristaltic pump. However, we were not able to reduce the fixation level to less than 40 p. 100 for any of the steroids tested. At the end of the incubation period, the fragments were removed, gently blotted, weighed and homogenized in the culture medium. The homogenates were immediately extracted ; $50 \mu \mathrm{g}$ of various unlabeled steroids were added as carriers. For aromatase activity determination, [4-14 C]-estradiol-17 $\beta(10000 \mathrm{dpm})$ and $[4-14 \mathrm{C}]$-estrone $(10000 \mathrm{dpm})$ were also added to the extracts as internal recovery standards.

Extraction. - The homogenized ovaries and the incubation media were extracted three times with $15 \mathrm{ml}$ of ether : chloroform $(3: 1)$ and once with $15 \mathrm{ml}$ of ethyl acetate. The organic phase was evaporated to dryness and resuspended in $1 \mathrm{ml}$ of methanol for steroid analysis.

Testosterone : 17 $\beta$-hydroxy-4-androsten-3-one.

DHT : dihydrotestosterone : 17 $\beta$-hydroxy-5 $\alpha$-androstan-3-one.

Estradiol-17 $\beta: 1,3,5(10)$ estratriene-3,17 $\beta$-diol.

Estriol : $1,3,5(10)$ estratriene-3,16 $\alpha, 17 \beta$-triol.

Estrone : 3 hydroxy-1,3,5 (10) estratrien-17-one.

onc-GTH : gonadotropin of Oncorhynchus tshawytsha.

aci-GTH : gonadotropin of Acipenser stellotus.

hCG : human chorionic gonadotropin hormone.

17ß-HSDH : 17 $\beta$-hydroxysteroid dehydrogenase (1.1.1.53). 
Chromatography. - Column chromatography was used to separate the androgens from the estrogens. The columns were prepared according to the method described by Adessi et al. (1976). A glass column $(1 \times 12 \mathrm{~cm})$ equipped with a $50-\mathrm{ml}$ bowl was filled with Dowex AG1-X2 resin, chloride form, 200-400 mesh (Bio-Rad), suspended in distilled water. The resin was allowed to settle (height : $4 \mathrm{~cm}$ ) and the column was washed as follows : $25 \mathrm{ml}$ of $\mathrm{H}_{2} \mathrm{O}, 2 \times 5 \mathrm{ml}$ of $\mathrm{NaHCO}_{3} 0.5 \mathrm{M}, 5 \mathrm{ml}$ of $\mathrm{H}_{2} \mathrm{O}, 20 \mathrm{ml}$ of 80 p. 100 methanol and $20 \mathrm{ml}$ of $100 \mathrm{p} .100$ methanol. The extracts were applied to the column with $3 \times 1 \mathrm{ml}$ of pure methanol. The androgens were eluted with $15 \mathrm{ml}$ of pure methanol and the estrogens with $40 \mathrm{ml}$ of 80 p. 100 methanol.

Thin-layer chromatography was performed on Merck silica gel $60 \mathrm{~F} 254$ using chloroform : ethyl acetate $(5: 1)$ and, when specified, chloroform : acetone $(9: 1)$. The ketosteroids and estrogens were visualized by ultraviolet light at $240 \mathrm{~nm}$. The peaks of radioactivity corresponding to androgens and estrogens were eluted.

Measurement of radioactivity. - The radioactive metabolites were detected using a Panax $X Y$ radiochromatogram scanner. The peaks were eluted with methanol and counted in $15 \mathrm{ml}$ of a toluene-PPO-POPOP system in a Packard Tricarb liquid scintillation spectrometer (model 3320) equipped with an external standard. Aqueous solutions $(1 \mathrm{ml})$ were counted in $10 \mathrm{ml}$ of a toluene-PPO-POPOP-Triton X-100 mixture.

Counting efficiency, determined by the use of an external standard, was approx. 38 p. 100 for ${ }^{3} \mathrm{H}$ and 55 p. 100 for ${ }^{14} \mathrm{C}$ when both isotopes were counted simultaneously. When ${ }^{14} \mathrm{C}$ was present alone, 10 p. 100 of the radioactivity appeared in the ${ }^{3} \mathrm{H}$ channel. At the end of the procedure, about 65 p. 100 of the ${ }^{14} \mathrm{C}$ tracers were recovered.

Aromatase activity. - In order to estimate the aromatase activity, the following ratio was calculated at the end of incubation after purification and chromatographic identification : radioactivity recovered in total isolated estrogens $\times 100 /$ total solvent extractable tritiated steroids per $\mathrm{mg}$ of fresh weight.

Identification of metabolites. - In all the experiments, each steroid was identified by checking the isopolarity of the peak of radioactivity with that of the authentic steroid in two chromatographic systems : (i) chloroform : ethyl acetate (5:1) and (ii) chloroform : acetone $(9: 1)$.

A complementary experiment was performed in July on a vitellogenic female (experiment T) employing the usual protocol. After purification and chromatographic identification, the synthesized steroids were divided into two parts and subjected either to microchemical reaction or to crystallization to a constant isotopic ratio.

a) Microchemical reactions. - All the metabolites were acetylated. The steroid was mixed with acetic anhydride $(500 \mu l)$ and pyridine $(500 \mu l)$ then left overnight at $20^{\circ} \mathrm{C}$. The acetates were subsequently hydrolyzed by 5 p. $100 \mathrm{KOH}$ in methanol for $1 \mathrm{hr}$ at $60^{\circ} \mathrm{C}$.

The 17-hydroxy group was oxidized with chromic acid. $500 \mu l$ of chromic acid (20 p. $100 \mathrm{CrO}_{3}$ in 32 p. $100 \mathrm{H}_{2} \mathrm{SO}_{4}$ ) were added to the steroid in $500 \mu$ l acetone. The mixture was left in the dark for $1 \mathrm{hr}$.

Estrogen reduction was obtained by treating the steroid with sodium borohydride for $1 \mathrm{hr}$ at $20^{\circ} \mathrm{C}$. Excess reagent was destroyed with a diluted solution of acetic acid. Androstenedione was treated in the same way but only for $30 \mathrm{~min}$. at $0{ }^{\circ} \mathrm{C}$. 
- Androstenedione : The radioactive substance, corresponding to a single peak which showed the same mobility as authentic androstenedione, could not be acetylated with pyridine and acetic anhydride. After treatment with $\mathrm{CrO}_{3}$ in acetic acid, the radioactive substance referable to androstenedione remained unchanged. Sodium borohydride reduction gave a product which was isopolar with testosterone in both the chromatographic systems.

- Testosterone : Acetylation gave an isopolar product with a testosterone acetate standard in system II. After hydrolysis of this product, the testosterone was identified by its isopolarity with the authentic steroid in both chromatographic systems. Oxidation of the initial radioactive substance provided a compound identical to androstenedione on thin-layer chromatography in both systems.

- Dihydrotestosterone : When the radioactive substance co-migrating with authentic $5 \alpha$-dihydrotestosterone was acetylated and chromatographied in system I or II, it provided a single peak showing the same mobility as the DHT acetate reference prepared from authentic $5 \alpha$-DHT. Acetate hydrolysis gave a product isopolar to authentic DHT.

- Estrogens : Acetylation of the radioactive substance, which showed the same mobility as the authentic estrogens, gave products isopolar to the corresponding authentic acetates in system II. These products were hydrolyzed into the radioactive products which were isopolar to the corresponding authentic steroids.

The radioactive substance identified as estradiol- $17 \beta$ by thin-layer chromatography was oxidized into a product which was isopolar to estrone in both chromatographic systems. The reduction of the initial radioactive substance gave a product isopolar to authentic estriol in system II.

The radioactive substance isopolar to estrone in system I or II was reduced to a product whose radioactivity was located at the same position as estradiol-17 $\beta$ in both chromatographic systems.

b) Crystallization to a constant isotopic ratio. - ${ }^{14} \mathrm{C}$-steroid, together with $20 \mathrm{mg}$ of the authentic steroid, was added to the ${ }^{3} \mathrm{H}$-steroid identified by thin-layer chromatography. The amount of ${ }^{14} \mathrm{C}$-steroid was settled so that the ${ }^{3} \mathrm{H} /{ }^{14} \mathrm{C}$ ratio was equal to 3 .

TABLE 2

Recrystallization to constant isotopic ratio of androsfenedione, testosterone, $5 \alpha$-dihydrotestosterone, estrone and estradiol-17 $\beta$ isolated from rainbow trout ovaries

\begin{tabular}{|c|c|c|c|c|c|}
\hline \multirow[b]{2}{*}{ Recrystallization } & \multicolumn{5}{|c|}{${ }^{3} \mathrm{H} /{ }^{\mathbf{1 4}} \mathrm{C}$ ratio } \\
\hline & Androstenedione & Testosterone & $\begin{array}{l}5 \alpha \text {-dihydro- } \\
\text { testosterone }\end{array}$ & Estrone & Estradiol-17 $\beta$ \\
\hline 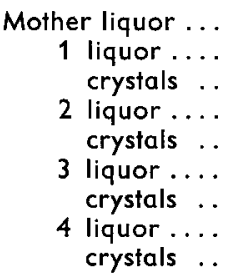 & $\begin{array}{l}3.43 \\
4.17 \\
3.34 \\
3.80 \\
3.88 \\
3.90 \\
3.82 \\
4.08 \\
3.84\end{array}$ & $\begin{array}{l}3.29 \\
3.80 \\
2.73 \\
3.01 \\
2.71 \\
3.27 \\
2.64 \\
3.05 \\
2.74\end{array}$ & $\begin{array}{l}3.34 \\
3.50 \\
3.15 \\
3.45 \\
3.69 \\
3.66 \\
3.62 \\
3.57 \\
3.73\end{array}$ & $\begin{array}{l}3.38 \\
3.45 \\
2.77 \\
2.98 \\
2.62 \\
2.71 \\
2.64 \\
- \\
-\end{array}$ & $\begin{array}{l}3.85 \\
3.62 \\
3.13 \\
3.92 \\
3.21 \\
3.78 \\
3.18 \\
3.08 \\
3.17\end{array}$ \\
\hline
\end{tabular}


Four successive recrystallizations from methanol/water were then performed to obtain a constant isotopic ratio (table 2).

\section{Results.}

1) Incubation in the presence of radioactive $C_{19}-\Delta^{4}-3-$ keto steroids. - After a 6-hr incubation period, the total steroids were isolated by Dowex AG1-X2 chromatography (see Material and methods). The $\mathrm{C}_{19^{-3}}$ keto-4ene-steroids were chromatographically separated and the androstenedione/testosterone ratio was measured. We found a reduction of androstenedione to testosterone at both the androstenedione concentrations used (table 3).

TABLE 3

Androstenedione-festosterone interconversion ofter 6-hr perifusion

\begin{tabular}{cccc}
\hline Precursor & Concentration & Animal * & $\begin{array}{c}\text { Androstenedione/ } \\
\text { testosterone }\end{array}$ \\
\hline & & $\mathrm{G}$ & 1.26 \\
Androstenedione & $5 \times 10^{-8} \mathrm{M}$ & $\mathrm{H}$ & 1.78 \\
\cline { 2 - 4 } & $5 \times 10^{-6} \mathrm{M}$ & $\mathrm{G}$ & 3.53 \\
\hline Testosterone & $5 \times 10^{-8} \mathrm{M}$ & $\mathrm{H}$ & 1.50 \\
& & $\mathrm{M}$ & 2.45 \\
\hline
\end{tabular}

* See table 1 . The ratio is calculated from radioactivity recovered after extraction of both the androgens.

TABLE 4

Aromatization of $\mathrm{C}_{19}$ steroids after 6-hr perifusion

\begin{tabular}{lccccc}
\hline Precursor & Concentration & Animal * & $\begin{array}{c}\text { Total isolated } \\
\text { steroids (dpm) } \\
\times 10^{-6}\end{array}$ & $\begin{array}{c}\text { Total isolated } \\
\text { estrogens }(\mathrm{dpm}) \\
\times 10^{-5}\end{array}$ & $\begin{array}{c}\text { Percent of } \\
\text { aromatization }\end{array}$ \\
\hline & $5 \times 10^{-8} \mathrm{M}$ & $\mathrm{G}$ & 7.71 & 7.58 & 9.8 \\
& $31.6 \times 10^{6} \mathrm{dpm} / \mathrm{nmol}$ & $\mathrm{H}$ & 7.47 & 21.47 & 28.7 \\
Androstenedione & & $\mathrm{K}$ & 7.60 & 14.52 & 19.1 \\
& & $\mathrm{~K}$ & 7.10 & 15.03 & 21.0 \\
& $5 \times 10^{-6} \mathrm{M}$ & $\mathrm{G}$ & 20.63 & 16.52 & 18.0 \\
\hline \multirow{2}{*}{ Testosterone } & $31.6 \times 10^{4} \mathrm{dpm} / \mathrm{nmol}$ & $\mathrm{H}$ & 20.60 & 47.37 & 8.0 \\
& $5 \times 10^{-8} \mathrm{M}$ & $\mathrm{L}$ & 20.58 & 94.73 & 46.0 \\
\hline & $18.5 \times 10^{6} \mathrm{dpm} / \mathrm{nmol}$ & $\mathrm{M}$ & 13.10 & 21.68 & 16.5 \\
& & $\mathrm{M}$ & 13.37 & 21.53 & 16.1 \\
\hline
\end{tabular}

* See table 1.

** The percent of aromatization is defined as radioactivity in estrogens/total solvent-extractable ${ }^{3} \mathrm{H}$ steroids $Y 100$. 
In our experimental conditions, 17 $\beta$-HSDH activity was reversible since 30 p. 100 of the testosterone was found to be transformed into androstenedione.

$5 \alpha$-Dihydrotestosterone (6 p. 100 of total recovered radioactivity) was identified (see Material and methods). The presence of $5 \alpha / \beta$-androstanedione (approximately 4 p. 100 of total recovered radioactivity) was detected by reference to the authentic markers chromatographied in 2 different systems : (i) benzene-ether $9: 1$ (twice at $4{ }^{\circ} \mathrm{C}$ ) and chloroform-ethyl acetate $5: 1$ (once at $20^{\circ} \mathrm{C}$ ) ; (ii) chloroform/acetone $9: 1$.

2) $C_{19}$ steroid-aromatase activity. - During perifusion with tritiated androstenedione or testosterone, both estradiol-17 $\beta$ and estrone were found to be formed (table 4).

Estrogen synthesis from tritiated testosterone was estimated as a function of the incubation time. It should be noted (fig. 1) that nearly maximum estrogen production

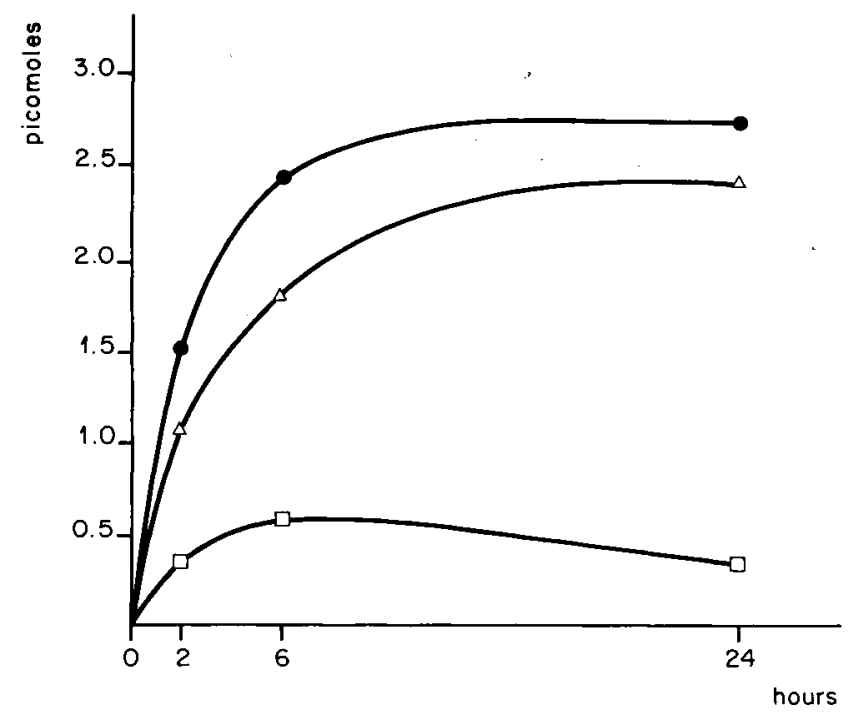

FIG. 1. - Synthesis of estrogens from tritiafed testosterone as a function of the incubation time (ovaries in the post ovulatory stage). pmoles of estrogens were calculated from the ratio:

$\frac{\text { radioactivity of recovered testosterone } \times \text { aromatization percent }}{\text { specific activity of the steroid }}$

Estradiol-17 $\beta$ : $\Delta$; estrone : $\square$; estradiol-17 $\beta$ + estrone : $\bullet$.

was obtained in $6 \mathrm{hrs}$ of incubation. This incubation time was used in all subsequent experiments. From the postovulatory period to vitellogenesis initiation, the ovarian tissue was capable of aromatizing androgens. Estradiol-17 $\beta$ was the predominant estrogen formed.

The aromatizing activity increased from November to July, i.e. from the postovulatory stage to exogenous vitellogenesis (oocyte diameter $>1 \mathrm{~mm}$ ) (table 5).

3) Effect of salmon gonadotropin. - The steroidogenic ability of the ovarian tissue was analyzed in the presence of salmon gonadotropin (onc-GTH) which was added to the perifusion medium at a concentration of 50,150 or $300 \mathrm{ng} / \mathrm{ml}$. 
TABLE 5

Aromatization percentage of tritiated androsfenedione $\left(5 \times 10^{-8} \mathrm{M}\right)$ into estrogens (estradiol-17 $\beta+$ estrone) ot different periods of the annual cycle

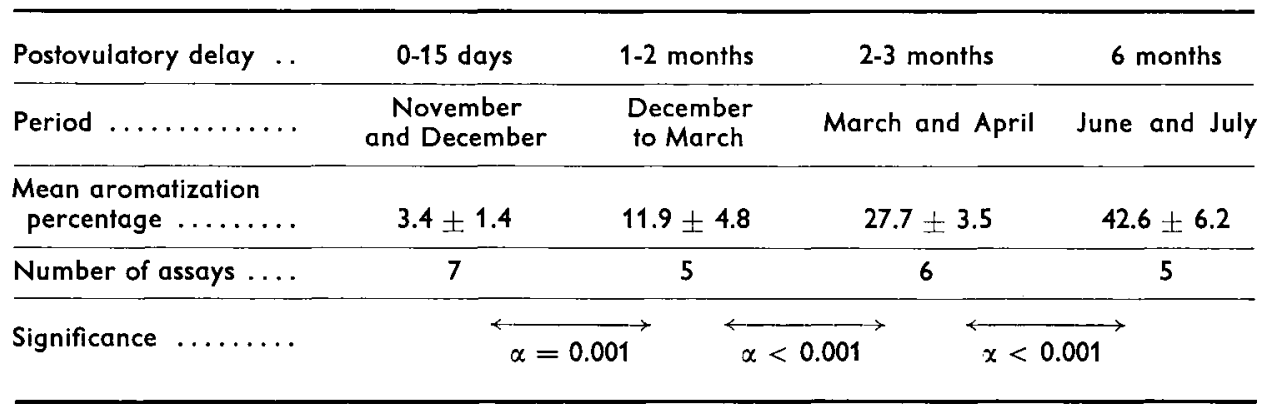

a) Androstenedione/testosterone ratio. - The presence of onc-GTH in the perifusion medium increased the conversion of androstenedione to festosterone since the androstenedione/testosterone ratio decreased as GTH concentration increased (table 6).

\section{TABLE 6}

Effect of GTH on the androstenedione/testosterone ratio

\begin{tabular}{ccc}
\hline & \multicolumn{2}{c}{ Androstenedione/testosterone ratio } \\
\cline { 2 - 3 } Animal * & Without GTH & $\begin{array}{c}\text { With GTH } \\
50 \mathrm{ng} / \mathrm{ml}\end{array}$ \\
\hline & & \\
G & 1.20 & 0.70 \\
H & 1.80 & 1.03 \\
J & 2.45 & 1.00 \\
N & 0.45 & 0.20 \\
& 2.63 & 2.00 \\
\hline
\end{tabular}

* See table 1.

The ratio decreases significantly ( $p<0.05$; paired Student's $t$ test) when GTH is added at a concentration of $50 \mathrm{ng} / \mathrm{ml}$.

This indicates that under in vitro conditions, $17 \beta-\mathrm{HSDH}$ activity favourizes the reduction of $17 \beta$-keto groups to $17 \beta$-hydroxy groups after GTH treatment.

b) Estrogen formation. - Estrogen synthesis from exogenous labeled precursors always seemed reduced when onc-GTH (50 to $300 \mathrm{ng} / \mathrm{ml})$ was added to the perifusion medium, whatever the precursor concentration used (table 7 ).

In all the experiments, estradiol-17 $\beta$ was the main steroid isolated; the estradiol$17 \beta /$ estrone ratio, which varied between 3 and 6 did not appear to depend on the GTH concentration.

\section{Discussion and conclusion.}

Our experiments demonstrate that aromatization enzymes operate in the trout 
TABLE 7

Effect of GTH on the aromatization percent ofter 6-hr perifusion

\begin{tabular}{|c|c|c|c|c|c|}
\hline Precursor & Concentration & Animal * & GTH $(\mathrm{ng} / \mathrm{ml})$ & $\begin{array}{l}\text { Aromatization } \\
\text { (p. 100) }\end{array}$ & $\begin{array}{l}\text { Percent of } \\
\text { inhibition }\end{array}$ \\
\hline \multirow[t]{2}{*}{ Androstenedione } & $5 \times 10^{-8} \mathrm{M}$ & $\begin{array}{l}G \\
1 \\
K\end{array}$ & $\begin{array}{r}0 \\
50 \\
0 \\
50 \\
0 \\
0 \\
50 \\
150 \\
300\end{array}$ & $\begin{array}{r}9.8 \\
7.9 \\
19.1 \\
12.1 \\
21.0 \\
18.0 \\
17.0 \\
12.0 \\
14.0\end{array}$ & $\begin{array}{l}\overline{19} \\
\overline{37} \\
\overline{-} \\
\overline{13} \\
38 \\
28\end{array}$ \\
\hline & $5 \times 10^{-6} \mathrm{M}$ & $\begin{array}{l}G \\
L\end{array}$ & $\begin{array}{r}0 \\
50 \\
0 \\
150\end{array}$ & $\begin{array}{r}8.0 \\
6.7 \\
46.0 \\
35.1\end{array}$ & $\frac{\overline{16}}{24}$ \\
\hline Testosterone & $5 \times 10^{-8} \mathrm{M}$ & $M$ & $\begin{array}{r}0 \\
0 \\
50 \\
50\end{array}$ & $\begin{array}{l}16.5 \\
16.1 \\
10.9 \\
11.3\end{array}$ & $\begin{array}{l}\overline{-} \\
33 \\
31\end{array}$ \\
\hline
\end{tabular}

* See table 1.

ovary at the major stages of the annual cycle. The estrogen production per cell (DNA content) could not be estimated since there was a large accumulation of extranuclear DNA in the yolk during vitellogenesis (in Salmo salar more than 90 p. 100 of the total DNA of the whole fertilized egg is in the yolk: Hamor and Garside, 1977 ; also see Tyler, 1967). The fresh weight can be considered as a valuable parameter for estimating gonadal aromatizing ability : the increase in ovarian weight during the annual cycle is mostly due to « inert » yolk accumulation rather than to endocrine cell multiplication. In these conditions, an increase of steroid production per unit of fresh weight would really be due to an increase of the biosynthetic activity of the tissue.

Both androstenedione and testosterone are convenient substrates for measuring the aromatizing activity of the trout ovary in perifusion. The androgen concentration we used $\left(5.10^{-8} \mathrm{M}\right)$ was in the range of endogenous androgen concentrations estimated by radioimmunoassay (unpublished results). Aromatizing activity varied during the annual cycle. Ovarian estrogen synthesis was at its minimum just after ovulation, then slowly increased to higher values at the beginning of exogenous vitellogenesis (which begins when oocyte diameter reaches $580 \mu \mathrm{m}$; Upadhyay, 1977). During that stage plasma estrogen values began to increase rapidly. These observations agree with the role assigned to estradiol- $17 \beta$ in the stimulation of vitellogenin synthesis in the liver (Campbell and Idler, 1976 ; Yaron ef al., 1977 ; Terkatin-Shimony and Yaron, 1978 ; Crim and Idler, 1978). The estradiol-17//estrone ratio studied at the different ovarian stages and as a function of perifusion time indicates that estradiol-17 $\beta$ is really the main estrogen synthesized from $C_{19}-\Delta^{4}-3$ keto steroids.

Lambert and Van Bohemen (1978), Van Bohemen and Lambert (1979), incubating ovarian homogenates of rainbow trout in presence of ${ }^{3} \mathrm{H}$-pregnenolone, showed that 
this steroid is a precursor of estrogen synthesis (by the $\Delta^{5}$ route) only during vitellogenesis. The lack of estrogen biosynthesis in their incubation system could be imputed to a low $\Delta^{5}$ - $3 \beta$-steroid oxydoreductase and/or $17 \beta$-hydroxylase activity. Nevertheless, androgens can be considered as more convenient precursors for accurately studying aromatizing activity than $\mathrm{C}_{21}$ steroids. When the latter are used as precursors, the radioactivity may be « scattered » among the various metabolites, thus masking a low estrogen production.

All our experiments showed that whatever the concentrations of gonadotropin $\left(5.10^{-8}\right.$ or $\left.5.10^{-6} \mathrm{M}\right)$, the conversion of androstenedione to testosterone was increased by adding GTH to the perifusion medium. These results demonstrate an effect on $17 \beta-$ hydroxysteroid dehydrogenase activity. To our knowledge, this is the first indication of the gonadotropic control of an enzymatic activity in the fish gonad.

The nature and amounts of endogenous androgens must be taken into account when interpreting the effect of adding gonadotropin. An apparent decrease in aromatization could be thought to be a consequence of the stimulation of the synthesis of the $\mathrm{C}_{19}$ steroids used as precursors (isotopic dilution effect). This possibility does not seem valid as the response pattern to gonadotropin appeared unchanged when the exogenous precursor concentration was increased one hundredfold (from $5 \times 10^{-8}$ to $\left.5 \times 10^{-6} \mathrm{M}\right)$.

In our in vitro conditions, when gonadotropin concentration increased from 50 to $300 \mathrm{ng} / \mathrm{ml}$, estrogen production by the vitellogenic ovary decreased. During vitellogenesis in vivo, there is a parallel increase in the concentrations of both plasma gonadotropin (GTH) and plasma estradiol-17 $\beta$ (Breton ef al., 1975). A rise of immunoreactive estradiol-17 $\beta$ was induced by administering GTH to females in early vitellogenesis (trout : Billard et al., 1978) or at the end of vitellogenesis (carp : Fostier et al., 1979). More recently, Idler and Campbell (1980) showed that a carbohydrate-rich gonadotropin (fraction adsorbed on ConA-Sepharose) was able to stimulate estradiol-17 $\beta$ synthesis when injected into juvenile rainbow trout. When those authors incubated in vitro ovaries collected from pituitary extract-treated fish, they detected estrogen production, whereas no estrogen synthesis was evidenced in the ovaries of control animals. No data concerning the in vitro effect of the purified gonadotropin was reported. As far as in vivo experiments are concerned, an hypothalamo-hypophyseal relay for the action of the injected extract cannot be excluded at this time.

Our experimental results obtained in vitro could be ascribed to the GTH concentration used as well as to the length of the incubation period. The depressive effect of GTH on ovarian estrogen production can also be related to the observations of Breton ef al. (1975) and Fostier ef al. (1979) : after the ovulatory period, the GTH level increases, whereas plasma estradiol- $17 \beta$ values decrease. In the range of the GTH concentrations we used in vitro, it does not seem possible to stimulate ovarian estrogen production when $17 \beta-H S D H$ activity is stimulated. In vitro as well as in vivo, GTH could have an inhibitory effect on ovarian estrogen production when its concentration reaches a threshold level. This inhibitory effect of a fish gonadotropin has been observed in amphibians. When the ovaries of Xenopus laevis were incubated in the presence of aci-GTH $(1 \mu \mathrm{g} / \mathrm{ml}$ ), estradiol-17 $\beta$ synthesis was depressed (Mulner ef al., 1978). Ozon (personal communication) studying the same species, recently observed a rapid decrease of estrogen concentrations in ovaries incubated in the presence of HCG. 
It should be noted that the modalities of gonadotropic action are very different in vivo than in our in vitro conditions. In vitro, a dose of gonadotropin is added at the beginning of incubation and is not renewed for $6 \mathrm{hrs}$. Conversely, in vivo, the circadian rhythmicity and pulsatility of gonadotropin secretion has been recently recognized (Zohar, 1980). Moreover, the half-life of gonadotropin is certainly very different in vitro than in vivo; this point is being studied at present by Zohar (1980).

The increasing estradiol-17 $\beta$ production in vitro in the presence of gonadotropin does not appear to be inconsistent with the existence of an inhibitory gonadotropic effect on aromatase enzymatic activity. Thus, the gonadotropic stimulation of the first steps of steroidogenesis, accompanying aromatase inhibition, could favourize progestagen production, especially during oocyte maturation. Fostier ef al. (1981) studying the in vitro-cultured follicles of rainbow trout during oocyte maturation, recently showed a stimulatory onc-GTH effect on the production of immunoreactive $17 \alpha$-hydroxy-20 $\beta$ dihydroprogesterone (the most probable follicular relay in maturational gonadotropic action).

According to the two-cell concept in mammals (Leung and Armstrong, 1980), estradiol-17 $\beta$ synthesis results from cooperative interaction between the cellular actions of $\mathrm{LH}$ and FSH. The cooperation of thecal and granulosa cells in estrogen synthesis has been recently evidenced in teleosts by Nagahama (1980). So, it is very interesting for comparative endocrinologists, using only one gonadotropin, to explore the modalities and the limits of the regulation of ovarian estrogen production in fish.

Reçu en janvier 1981.

Accepté en avril 1981.

Acknowledgements. - The authors are greatly indebled to Professor R. Ozon of the Université Pierre-et-Marie-Curie, Paris for his sustaining interest in this research and his criticisms of the manuscript. They also wish to thank Dr. B. Breton, INRA Rennes, for the gifts of purified gonadotropin and Dr. R. Billard, INRA Jouy-en-Josas, for valuable discussion and his gift of the trout. The assistance of Dr. O. Mulner was greatly appreciated during the early part of this study.

Résumé. L'activité aromatase a été étudiée dans l'ovaire de la truite arc-en-ciel incubé en périfusion. Au début de la vitellogenèse comme à d'autres stades du cycle annuel, l'ovaire est capable d'aromatiser l'androstènedione et la testostérone. L'activité aromatase augmente des stades préovulatoires à la vitellogenèse exogène. L'addition au milieu de périfusion de gonadotropine de saumon hautement purifiée $(50 \mathrm{ng} / \mathrm{ml})$ entraîne une diminution de 50 p. 100 environ du rapport androstènedione/festostérone, ce qui indique une stimulation de l'activité $17 \beta$-hydroxystéroïde déshydrogénase favorisant la production de testostérone. Aux concentrations de 50,150 ou $300 \mathrm{ng} / \mathrm{ml}$, la gonadotropine inhibe l'activité aromatase dans la proportion de 13 à 38 p. 100.

\section{References}

ADESSI G., GOUTTE-COUSSIEU C., NHUAN T. Q., JAYLE M. F., 1976. Aromatisation de la testostérone par le placenta de cobaye in vitro. Biochimie, 58, 373-375.

BILLARD R., BRETON B., FOSTIER A., JALABERT B., WEIL C., 1978. Endocrine control of the teleost reproductive cycle and its relation to external factors : salmonid and cyprinid models, 37-48. In : GAILLARD P. J., BOER H. H., Comparative endocrinology, Elsevier North Holland, Biomed. Press, Amsterdam. 
BRETON B., JALABERT B., FOSTIER A., BILLARD R., 1975. Etude sur le cycle reproducteur de la truite arc-en-ciel et de la fanche. Effet de variations expérimentales de la température. J. Physiol. (Paris), 30, 561-564.

BRETON B., PRUNET P., REINAUD P., 1978. Sexual differences in salmon gonadotropin. Ann. Biol. anim. Bioch. Biophys., 18, 759-765.

CAMPBELL C. M., IDLER D. R., 1976. Hormonal control of vitellogenesis in hypophysectomized winter flounder (Pseudopleuronectes americanus Walbaum). Gen. comp. Endocrinol, 28, 143-150.

CRIM L. W., IDLER D. R., 1978. Plasma gonadotropin, estradiol, and vitellogenin and gonad phosvitin levels in relation to the seasonal reproductive cycles of female brown trout. Ann. Biol. anim. Bioch. Biophys., 18, 1001-1005.

EAGLE H., 1959. Amino acid metabolism in mammalian cell cultures. Science, 130, 432-437.

FOSTIER A., WEIL C., TERQUI M., BRETON B., JALABERT B., 1978. Plasma estradiol-17 $\beta$ and gonadotropin during ovulation in rainbow trout (Salmo gairdneri R.). Ann. Biol. anim. Bioch. Biophys., 18, 929-936.

FOSTIER A., BRETON B., JALABERT B., 1979. Stimulation hypophysaire de la sécrétion d'œstradiol$17 \beta$ chez la carpe commune, Cyprinus carpio L. Ann. Endocrinol. (Paris), 40, 83-84.

FOSTIER A., JALABERT B., CAMPBELL C., TERQUI M., BRETON B., 1981. Cinétique de libération in vitro de $17 \alpha$-hydroxy-20 $\beta$ dihydroprogestérone par des follicules de truite arc-en-ciel, Salmo gairdneri. C. R. Acod. Sci. (under press).

HAMOR T., GARSIDE E. T., 1977. Quantitative composition of the fertilized ovum and constituent parts in the Allantic salmon Salmo salar L. Conod. J. Zool., 55, 1650-1655.

IDLER D. R., CAMPBELL C. M., 1980. Gonadotropin stimulation of estrogen and yolk precursor synthesis in juvenile rainbow trout. Gen. comp. Endocrinol., 41, 384-391.

JALABERT B., BRETON B., BILLARD R., 1974. Dosage biologique des hormones gonadotropes de poisson par le test de maturation in vitro des ovocytes de truite. Ann. Biol. anim. Bioch. Biophys., 14, 217-228.

LAMBERT J. G. D., BOSMAN G. I. C. G. M., VAN DEN HURK R., VAN OORDT P. G. W. J., 1978. Annual cycle of plasma estradiol-17 $\beta$ in the female trout Salmo gairdneri. Ann. Biol. anim. Bioch. Biophys., 18, 923-927.

LAMBERT J. G. D., VAN BOHEMEN C. G., 1978. Steroidogenesis in the ovary of the rainbow trout Salmo gairdneri. Satellite Symp. Hormonal steroids in fish, Delhi, 4-5.

LEUNG C. K., ARMSTRONG D. T., 1980. Interactions of steroids and gonadotropins in the control of steroidogenesis in the ovarian follicle. Ann. Rev. Physiol., 42, 71-82.

MÉNÉZO Y., 1976. Milieu synthétique pour la survie et la maturation des gamètes et pour la culture de l'œu fécondé. C. R. Acad. Sci. Paris, Sér. D, 282, 1967-1986.

MULNER O., THIBIER C., OZON R., 1978. Steroid biosynthesis by ovarian follicle of Xenopus laevis in vifro during oogenesis. Gen. comp. Endocrinol., 34, 287-295.

NAGAHAMA Y., 1980. (Under press). Symp. Physiology and behaviour of fish, Am. zool. Ass., Seattle.

TERKATIN-SHIMONY A., YARON Z., 1978. Estrogens and estrogenic effects in Tilapia aurea (Cichlidae Teleostei). Ann. Biol. anim. Bioch. Biophys., 18, 1007-1012.

TYLER A., 1967. Masked messenger RNA and cytoplasmic DNA in relation to protein synthesis and processes of fertilization and determination in embryonic development. In LOCKE M., Control mechanisms in developmental processes, Acad. Press, New York and London.

UPADHYAY S. N., 1977. Morphologie des gonades immatures et éfudes expérimentale de l'induction de la gamétogenèse chez la truite arc-en-ciel juvénile (Salmo gairdneri Rich.). Th. Doct. Etat, Paris.

VAN BOHEMEN C. G., LAMBERT J. C. D., 1979. Steroidogenesis in the ovary of the rainbow trout (Salmo gairdneri). J. Endocrinol., 80, 37-38.

WHITEHEAD C., BROMAGE N. R., FORSTER J. R. M., MATY A. J., 1978. The effects of alterations in photoperiod on ovarian development and spawning time in the rainbow trout Salmo gairdneri. Ann. Biol. anim. Bioch. Biophys., 18, 1035-1043.

WINGFIELD J. C., GRIMM A. S., 1977. Seasonal changes in plasma cortisol, testosterone and estradiol-17 $\beta$ in the plaice, Pleuronectes platessa L. Gen. comp. Endocrinol., 31, 1-11.

YARON Z., TERKATIN-SHIMONY A., SHAHAN A. Y., SALZER H., 1977. Occurrence and biological activity of estradiol-17 $\beta$ in the intact and ovariectomized Tilapia aurea. Gen. comp. Endocrinol., 33, 45-52.

ZOHAR Y., 1980. Unpublished data. 